\title{
Life-history features of a rapids-dwelling loricariid catfish from Atlantic forest streams, Brazil
}

\author{
Marcelo Fulgêncio Guedes Brito ${ }^{1,3}$, Henrique Lazzarotto $^{2}$ \& Erica Pellegrini Caramaschi ${ }^{2}$ \\ ${ }^{1}$ Universidade Federal de Sergipe, Programa de Pós-Graduação em Ecologia e Conservação, Av. Marechal \\ Rondon, s/n, 49100-000, São Cristóvão, SE, Brazil. \\ ${ }^{2}$ Universidade Federal do Rio de Janeiro, Departamento de Ecologia, Laboratório de Ecologia de Peixes, \\ Rio de Janeiro, RJ, Brazil. \\ ${ }^{3}$ Corresponding author: Marcelo Fulgêncio Guedes Brito, e-mail: marcelictio@gmail.com
}

BRITO, M.F.G., LAZZAROTTO, H., CARAMASCHI, E.P. Life-history features of a rapids-dwelling loricariid catfish from Atlantic forest streams, Brazil. Biota Neotropica. 16(2): e20150068. http://dx.doi. org/10.1590/1676-0611-BN-2015-0068

\begin{abstract}
Spatial distribution, suitable spawning sites, and sexual dimorphism were investigated in armored catfish Neoplecostomus microps in the Macaé River from March 2004 to March 2005. Individuals of $N$. microps $(\mathrm{n}=290)$ were limited to fast-flowing stretches, and the distribution was related to ontogenetic development. Larvae in post-flexion occurred in the marginal vegetation, and adults only in gaps between boulders and stones in the river channel. Juveniles occurred in both environments. Spawns were found in the natural habitat in rapid stretches, with the eggs attached to the lower surface of stones in openings formed in the riverbed. The number of eggs per stone ranged from 62 to 375 , with significant differences among the mean sizes of the eggs. Sexual dimorphism was noticed to $N$. microps. The anal and urogenital papillae are separated in males and merged in females and there is an epidermal growth along the pectoral-fin spine of males.
\end{abstract}

Keywords: Neoplecostomus microps, Loricariidae, distribution, spawn, sexual dimorphism.

BRITO, M.F.G., LAZZAROTTO, H., CARAMASCHI, E.P. Atributos da história de vida de um cascudo de corredeiras de riachos de Mata Atlântica, Brasil. Biota Neotropica. 16(2): e20150068. http:// dx.doi.org/10.1590/1676-0611-BN-2015-0068

Resumo: Distribuição espacial, locais favoráveis à desova e dimorfismo sexual foram estudados no cascudo Neoplecostomus microps no rio Macaé de março 2004 a março 2005. Espécimes de N. microps estiveram restritos a trechos de águas rápidas, e sua distribuição foi relacionada ao desenvolvimento ontogenético. Larvas em pós-flexão ocorreram somente na vegetação marginal e adultos somente em frestas entre rochas e pedras no canal do rio. Juvenis ocorreram em ambos ambientes. Desovas foram encontradas no ambiente natural em trechos de corredeira, com os ovos aderidos a superfície ventral de rochas em aberturas formadas com o leito do rio. O número de ovos/pedra variou de 62 a 375, com diferenças significativas entre os valores médios dos ovos. Dimorfismo sexual foi verificado em N. microps. As papilas anal e urogenital são separadas em machos e colabadas em fêmeas, e há uma projeção epidérmica na nadadeira peitoral de machos.

Palavras-chave: Neoplecostomus microps, Loricariidae, distribuição, desova, dimorfismo sexual.

\section{Introduction}

For fishes that inhabit regions of river rapids, the current speed and the complexity of the flow around obstacles and close to the riverbed are some of the most important factors affecting their distribution (Vannote et al. 1980, Allan 1995, Matthews 1998). One of the most successful groups occupying fast-flowing habitats in the Neotropical region is the family Loricariidae (Reis et al. 2003). They show several adaptations for moving in strong current or preventing them from being washed away. In some species, the elongated pectoral fins help to keep the fish fixed in place by friction, also acting as a hydrofoil, using the strength of the current to hold the fish against the substrate (Webb 1989).
Their suckermouth functions as an organ of adherence, fixing the fish to the substrate and avoiding drifting (Hora 1930). The choice of a favorable breeding site in this type of environment requires caution, because the spawn must be protected from the water flow, and, in some cases, by means of parental care (Balon 1975).

These features are recognized in several species of loricariids, including the genus Neoplecostomus, small-sized rapid-dwelling fishes with little-known life histories (FerrarisJr. 2003). The genus is currently represented by 14 species (Andrade \& Langeani 2014).The armored catfish Neoplecostomus microps (Steindachner 1877) occurs in the Paraíba do Sul River basin and adjacent coastal rivers (Langeani 1990, 
Buckup 2007) in southeastern Brazil. Information about the diet and reproductive dynamics of $N$. microps in mountainstreams of the upper Paraíba do Sul River basin was presented by Braga et al. (2008). However, these authors did not report information on the spatial distribution and spawning sites. In the present study, we present the first records of $N$. microps spawns in natural habitats and describe sexual dimorphic characters of this species. The patterns of spatial distribution of the different-sized individuals in a mesohabitat and microhabitat scales are also described and discussed.

\section{Material and Methods}

The Macae River is a seventh-order river located in northern Rio de Janeiro State, southeastern Brazil ( $22^{\circ} 21^{\prime} 22^{\circ} 28^{\prime} \mathrm{S} ; 42^{\circ} 27^{\prime}$ $\left.42^{\circ} 35^{\prime} \mathrm{W}\right)$. The basin of this river lies within the region with the highest rate of endemism for fishes of the Atlantic Forest (MMA 2000), and is one of the largest drainages in the State of Rio de Janeiro, draining directly into the Atlantic Ocean from altitudes up to $1,700 \mathrm{~m}$. The river channel at upper and middle stretches of the Macaé River and its tributaries is characterized by sequences of pools and riffles. The streambed consisted of stones and boulders, and occasionally gravel. In the lower portion, the river flows predominantly on sandy and muddy substrate.

The longitudinal distribution of $N$. microps was assessed by sampling in 12 locations equally distributed throughout the upper, middle and lower stretches of the Macaé River and in major tributaries. The fish sampling was performed bimonthly between March 2004 and March 2005.

To assess the species' distribution in the mesohabitat, the occurrence of individuals in riffles and pools was evaluated. In the riffles, the current was fast (Global Flow Probe FP101) $\left(1.29 \pm 0.32 \mathrm{~m} \mathrm{~s}^{-1}\right)$ and water depths (graduated scale) were typically less than $30 \mathrm{~cm}$. The pools were located between stretches of rapids, had mainly sandy bottom, and commonly contained deposits of leaves and detritus. The pools were always deeper than the runs and riffles, with a slower current $\left(0.24 \pm 0.13 \mathrm{~m} \mathrm{~s}^{-1}\right)$. Two microhabitats were evaluated within each mesohabitat, the river channel and the marginal region. In fast-flowing stretches, marginal microhabitats presented mainly live vegetation of Zingiberaceae. On the other hand, the substrate in the river channel was composed exclusively by medium to large-sized rocks and boulders.

The specimens were collected using sieves $(40 \times 60 \mathrm{~cm}$; mesh sizes $5 \mathrm{~mm}$ and $500 \mu \mathrm{m})$, drift net $(50 \mathrm{~cm}$ diameter; mesh $500 \mu \mathrm{m})$ and conical net $(1.5 \mathrm{~m} \mathrm{x} 1 \mathrm{~m}$; mesh $5 \mathrm{~mm})$ in the river channel. In this last method, rocks on the riverbed are picked up and moved, exploiting the current to carry fish, benthic invertebrates, leaves and debris toward the net, which is below the disturbed area, retaining all organisms. The fish longer than $3 \mathrm{~cm}$ were collected with $5 \mathrm{~mm}$ mesh (sieve and conical net) and fixed in $10 \%$ formalin; juveniles and larvae caught with $500 \mu \mathrm{m}$ mesh (sieve and drift net) were fixed in $4 \%$ buffered formalin (Nakatani et al. 2001). Environmental parameters were measured using YSI 30 (temperature and electrical conductivity) and YSI 55 (dissolved oxygen). Voucher specimens of adults were deposited in the Museu Nacional do Rio de Janeiro under number MNRJ 39018.

The specimens collected were measured and then dissected $(n=219)$ for confirmation of the sex and reproductive phase (Brown-Peterson et al. 2011). A Student's T test was used to evaluate differences in SL between genders.
The number of size classes of $N$. microps was determined by the Sturges rule, where $\mathrm{K}=1+3.222 \times \log n$, where $n$ is the sample size. The interval between the classes was generated based on $\mathrm{H}=\mathrm{R} / \mathrm{K}$, where $\mathrm{R}$ is the amplitude of standard length, and $\mathrm{K}$ is the number of classes (Sturges 1926). The sizes of the specimens collected in the marginal region and in the channel were compared using Student's T test (Zar 1996).

During the collections, stones and boulders larger than $30 \mathrm{~cm}$ were moved and had their undersides examined, to locate spawns. Each spawn was photographed, and some eggs were removed and immediately fixed in $4 \%$ buffered formalin for subsequent measurement on the diameters. Then, the stones were repositioned in the original position and their two major axes were measured from the insertion point on the riverbed. Dissection of eggs with embryos in advanced stage of development and comparison with larvae confirmed that the spawns belong to $N$. microps.

The photographs taken in the field were used for egg counting. Unhatched eggs and empty shells were included in the counts. The diameters of the eggs collected were measured with a stereoscopic microscope fitted with a micrometer lens.

The Shapiro-Wilk test was applied to verify normality of the egg-diameter data for each stone. Because the data did not indicate a normal distribution, they were submitted to the nonparametric Kruskal-Wallis test to compare the egg diameter of different stones. In cases where there was a significant difference, the post-hoc $\mathrm{H}$ test of multiple comparisons was performed (Zar 1996).

\section{Results}

Neoplecostomus microps occurred in the middle and upper stretches of the Macaé River and tributaries, at altitudes between 50 and $1090 \mathrm{~m}$. Specimens were captured only in fast-flowing habitats. At the capture sites, water temperature ranged from 11.6 to $25.3^{\circ} \mathrm{C}$, electrical conductivity from 12.2 to $73.2 \mu \mathrm{S} \mathrm{cm}^{-1}$ and dissolved oxygen from 7.45 to $10.78 \mathrm{mg} \mathrm{L}^{-1}$.

A total of 290 specimens of $N$. microps were collected, 242 of them in the river channel, 47 in the river margin and one in the drift. Of this total, 117 were males, 102 females and 71 were of indeterminate sex (all of them below $30 \mathrm{~mm} \mathrm{SL}$ ). The standard length (SL) ranged from $7.5 \mathrm{~mm}$ to $99.0 \mathrm{~mm}$. Males were generally larger than females (mean SL $66.6 \mathrm{~mm}$ vs. $57.9 \mathrm{~mm}$, respectively; $p<0.001$ ). The largest female measured $80.0 \mathrm{~mm}$, and the largest male $99.0 \mathrm{~mm}$. The smallest female and smallest male found to be reproductively active were $58.0 \mathrm{~mm}$ and $64.0 \mathrm{~mm}$, respectively.

Nine size classes were determined, with intervals of $10.25 \mathrm{~mm}$ between the classes. The distribution of sizes in the rapids showed a difference related to ontogenetic development ( $t$ test, $\mathrm{t}=10.71, p<0.0001$ ). Post-flexion larvae and juveniles from $7.50 \mathrm{~mm}$ to $32 \mathrm{~mm} \mathrm{SL}$ (classes 1 to 3 , Figure 1) occurred almost exclusively in the marginal vegetation. Juveniles and adults with standard lengths between $27 \mathrm{~mm}$ and $99 \mathrm{~mm}$ (classes 2 to 9) were reported in rapids, in gaps between stones and boulders on the riverbed (Figure 1). Classes 2 and 3 were the only ones with specimens collected in both marginal and channel microhabitats (Figure 1).

During the analysis, external morphological differences were observed, suggesting sexual dimorphism. The dissections confirmed that the differences were of sexual nature, even in juveniles. Males of $N$. microps show an epidermal growth along 


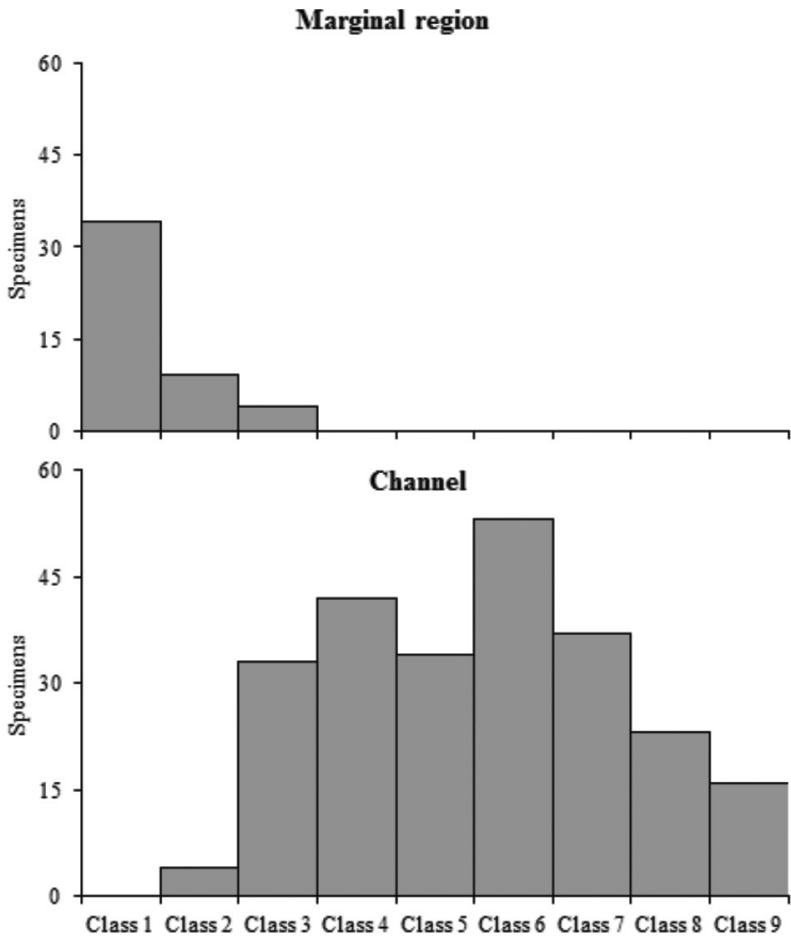

Figure 1. Histogram of the size classes of Neoplecostomus microps collected in the marginal region and channel of the Macaé River, Rio de Janeiro State, from March 2004 to March 2005.

the pelvic-fin spine, forming a flap that projects toward the side of the body (Figures 2b and 2c); this flap was observed in specimens from $32 \mathrm{~mm}$ SL. No females showed this epidermal expansion (Figure 2a).

Another difference observed between the sexes was in the genital area. In $N$. microps females, the anal and urogenital pores were very close, with the middle of the papillae merged, giving the appearance of a single opening (Figure 3a). The males showed a separation between the anal and urogenital pores, featuring two distinct and defined openings (Figure 3b).

Spawns were found in two sites in the Macaé River basin, in November 2004 and January 2005, during the rainy season, exclusively in rapid stretches. Of the total of eight spawns found, six were in the upper Macaé River, at $850 \mathrm{~m}$ altitude (site RM3), and two in the Boa Esperança River (site RBE), a left tributary of the middle Macaé River, at $651 \mathrm{~m}$ altitude (Table 1). The characteristics of the sites were similar, with the fast-flowing portion associated with stones and boulders (i.e. headwaters).

Eggs of $N$. microps were found attached to the undersides of eight stones, in cavities formed in the river bottom. The number of eggs per stone ranged from 62 to 375 (Table 1). Eggs in different stages of development were found on the same stone (Figures 4a, 4b, 4c and 4f). The egg colors ranged from yellow-gold, in eggs full of yolk in early development (Figure $4 d$ ), to brown, in eggs with pigmented embryos (Figure 4e) in an advanced stage of development.

The mean diameter of eggs was $4.0 \mathrm{~mm}$, with significant differences in the mean diameter of the eggs on different stones $(\mathrm{KW}=37.84, p<0.001)$. The greatest variation in diameter occurred in stone VIII, and eggs on stone III differed in diameter from the eggs of the other stones (Table 1). The stone
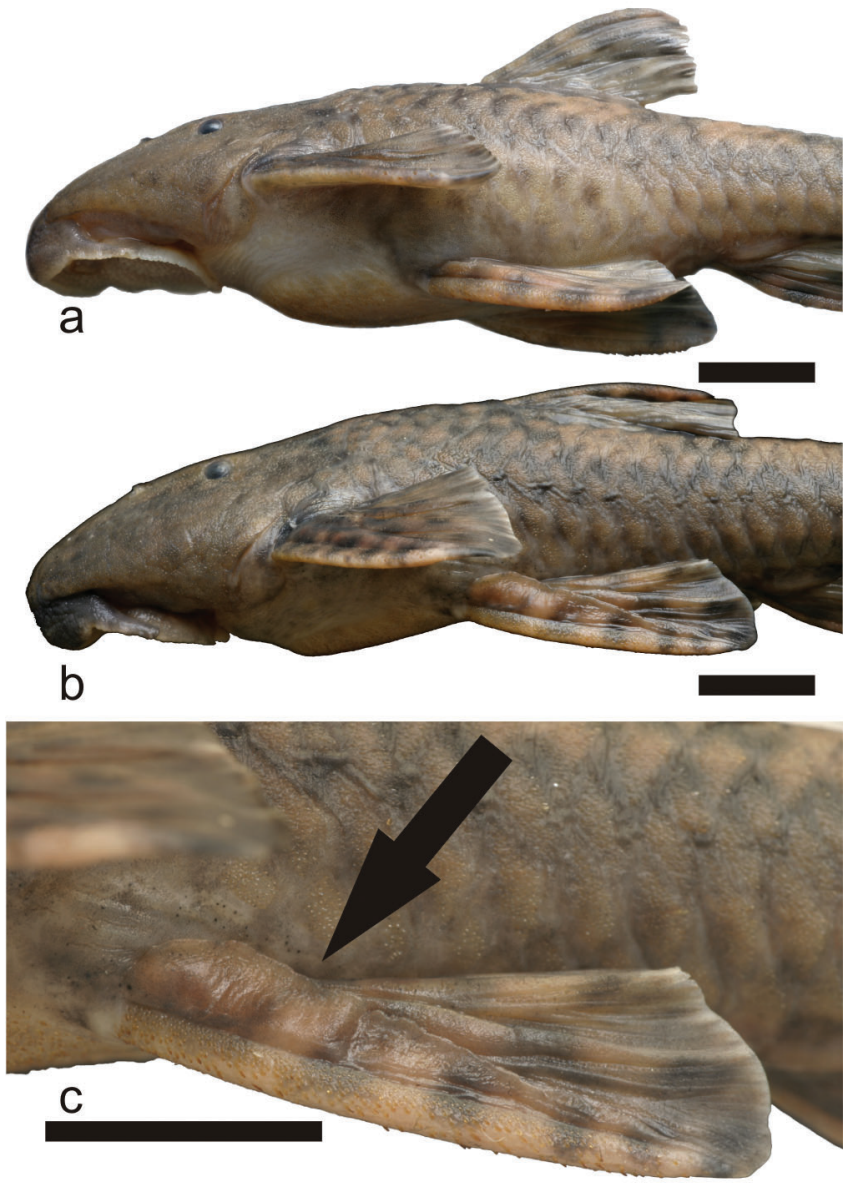

Figure 2. Lateral view of specimens of Neoplecostomus microps: a - female; $\mathrm{b}$ - male; $\mathrm{c}$ - detail of the epidermal growth (arrow) along the pelvic-fin spine of a male Neoplecostomus microps. Bar $=1 \mathrm{~cm}$.

with spawn $\mathrm{V}$ attached to the riverbed could not be removed, and therefore the number and sizes of the eggs were not determined. The current speed at the location of each spawnbearing stone ranged from $0.97 \mathrm{~m} / \mathrm{s}$ to $1.97 \mathrm{~m} / \mathrm{s}$ (Table 1). The largest stone with a spawn corresponded to spawn IV, and the smallest stone had spawn VIII (Table 1).

\section{Discussion}

Neoplecostomus microps occurred only in fast-flowing stretches with stones and boulders, typical of the upper and middle stretches of the Macaé River. Neoplecostomus microps was not recorded in the lower portion of the Macaé River, where the flow is slow and the substrate is sand and mud. This species has its life cycle restricted to the rapids. In this environment, $N$. microps of smaller size classes occur in the marginal vegetation and specimens of larger classes were captured in the river channel. Although $N$. microps is known to occur in altered habitats, the vegetation specificity where young individuals were found (almost exclusively Zingiberaceae) highlights the importance of the native vegetation in the life cycle of this species. In addition, silting caused by deforestation could alter substrate composition, rapids dynamics and spawning sites, thus affecting the species' longitudinal and spatial distribution. This spatial segregation can be related to limited or even absent swimming 
Table 1. Spawns of Neoplecostomus microps in the Macaé River (RM3) and Boa Esperança River (RBE), number of eggs on stone (N), number of eggs measured (M), maximum, minimum and mean diameter of eggs, mean current speed at the stone site, stone size (SS), and results of the H test (H) for significance among the sizes of eggs. $\mathrm{NM}=$ Not measured, ${ }^{*} p<0.05 ; * * p<0.005 ; * * * p<0.001$.

\begin{tabular}{|c|c|c|c|c|c|c|c|c|c|}
\hline Spawn & Site & $\mathbf{N}$ & $\mathbf{M}$ & $\begin{array}{l}\text { Max } \\
(\mathbf{m m})\end{array}$ & $\begin{array}{c}\text { Min } \\
(\mathbf{m m})\end{array}$ & $\begin{array}{l}\text { Mean } \\
(\mathbf{m m})\end{array}$ & $\begin{array}{l}\text { Vel } \\
(\mathrm{m} / \mathrm{s})\end{array}$ & $\begin{array}{l}\text { SS } \\
(\mathrm{cm})\end{array}$ & $\mathbf{H}$ \\
\hline I & RM3 & 375 & 24 & 4.3 & 3.6 & 3.9 & 1.10 & 63 X 51 & I x III** \\
\hline II & RM3 & 240 & 25 & 4.3 & 3.5 & 4.0 & 1.46 & $43 \times 44$ & II x III** \\
\hline III & RM3 & 177 & 15 & 4.4 & 4.0 & 4.2 & 1.30 & $37 \times 32$ & 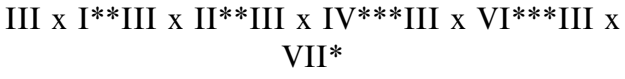 \\
\hline IV & RM3 & 103 & 16 & 4.0 & 3.6 & 3.9 & 1.97 & 74 X 56 & IV $x \mathrm{III}^{* * *}$ \\
\hline V & $\mathrm{RBE}$ & NM & NM & NM & NM & NM & 0.97 & $61 \times 36$ & $\mathrm{NM}$ \\
\hline VI & RBE & 62 & 18 & 4.0 & 3.6 & 3.8 & 1.13 & $36 \times 35$ & VI x III***VI x VIII* \\
\hline VII & RM3 & 70 & 14 & 4.3 & 3.8 & 4.0 & 1.31 & $47 \times 34$ & VII x III* \\
\hline VIII & RM3 & 112 & 24 & 4.5 & 3.5 & 4.0 & 1.28 & $36 \times 20$ & VIII x VI* \\
\hline
\end{tabular}

performance of juveniles to persist in rapids due to higher water velocity (Nikolsky 1963). The presence of juveniles in margin and a rare capture in drift may be associated to short period of drift, as observed to other rapids-dwelling catfishes (Brown \& Armstrong 1985). This spatial segregation would also avoid intraspecific competition in species with the same preferences at different stages of life (Arratia 1983, Garutti \& Figueiredo-Garutti 2000).

The care given to offspring implies both modifications in the parents' bodies to protect or carry their young, and a

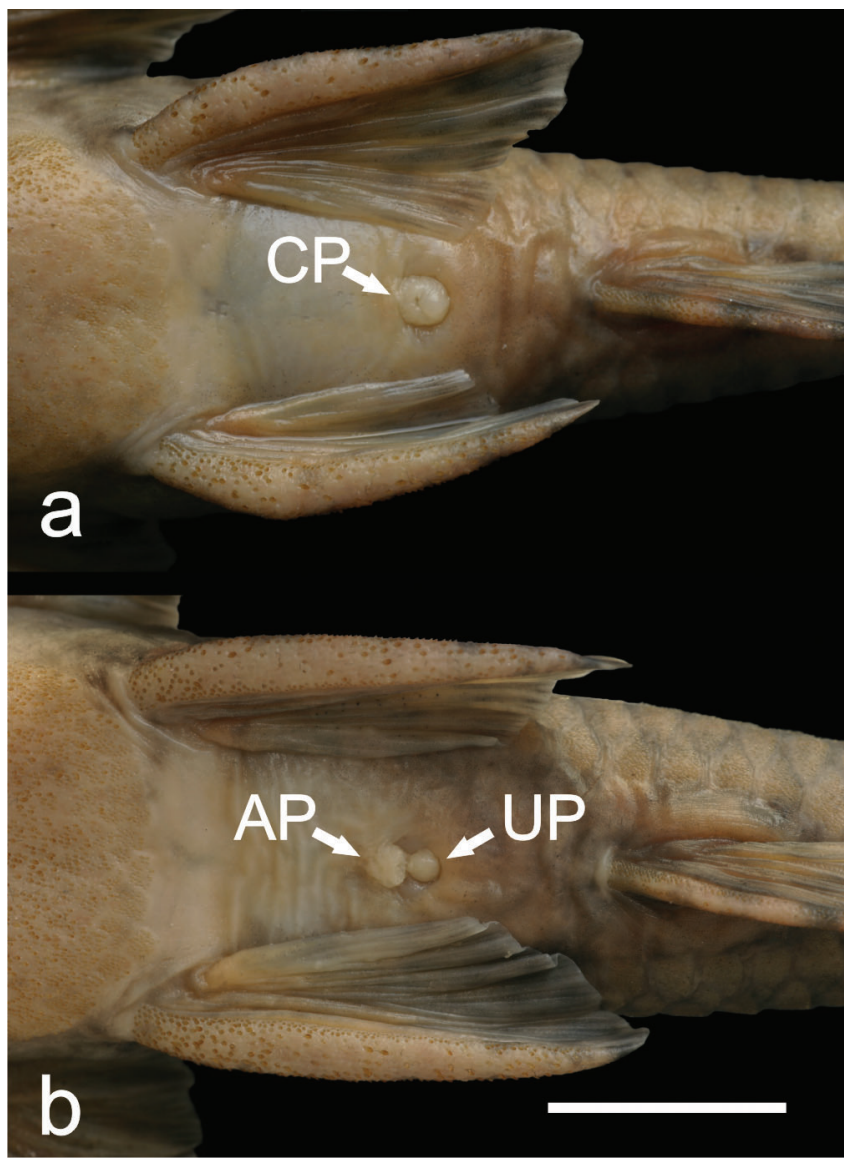

Figure 3. Detail of the ventral region of specimens of Neoplecostomus microps, showing the merged anal and urogenital pores (CP) in females (A), and the distinct anal pore (AP) and urogenital pore (UP) in males (B). $\mathrm{Bar}=1 \mathrm{~cm}$. greater investment in egg quality, i.e., a larger amount of yolk. The spawns of $N$. microps found in the natural environment had a small number of large, adherent eggs. This seems to be a common character for Loricariidae that provide care for the offspring, represented by species that lay their eggs in cavities (Moodie \& Power 1982, Sabaj et al. 1999, Cruz \& Langeani 2000) and by species that carry their eggs attached to the body (Menezes 1949, Taylor 1983, Schmidt 2001). Furthermore, larger oocyte size is associated with larger embryo/fry size, which increases the chance of survival of the offspring in unstable environments (Nikolsky, 1963).

The presence of $N$. microps eggs with different sizes and in different stages of development on the same stone suggests that the same female spawned more than once or that more than one female spawned at that site. This variation in egg size may be associated with age (larger females produce larger oocytes), asynchronous spawning (reduction in the size of oocytes from previous spawnings), nutrition (proper diet during gonadal maturation provides nutrient transfer) and genetics (quality of oocytes) (Brooks et al. 1997, Einum \& Fleming 2002, Kunz 2004). Reproduction with different partners, as recorded for other Loricariidae, both in the natural environment (Moodie \& Power 1982 - Loricaria uracantha) and in captivity (Sabaj et al. 1999 - Ancistrus spp.), also appears to occur in N. microps. Considering the low fecundity (44 to 54 oocytes found by Braga et al. 2008; 32 to 55 oocytes found by Alves et al. unpublished) and the relatively high numbers of eggs (up to 375 ) found in $N$. microps nests, it is probable that the male mates with more than one female.

Apparently, one factor in choosing a stone is the presence of cavities or gaps (formed between the stone and riverbed) appropriate for the surface, size and position relative to the current. Larger stones may also have a stronger support on the river bottom and thus have a smaller surface available for laying eggs. This may be observed in spawns IV and VIII, with similar numbers of eggs but on stones of different sizes. Another important factor was the shape of the stone. Round stones may provide a smaller surface for laying eggs than flatter stones, as well as being potentially less stable in strong current. Hiding the spawn in a hole or in a cavity does not mean that the offspring will be actively protected by the parent. However, the location and the environmental disturbances were significant factors in determining the spawning sites. The choice of larger stones for spawning in the rapids demonstrates the caution of $N$. microps in avoiding stones that can be displaced 

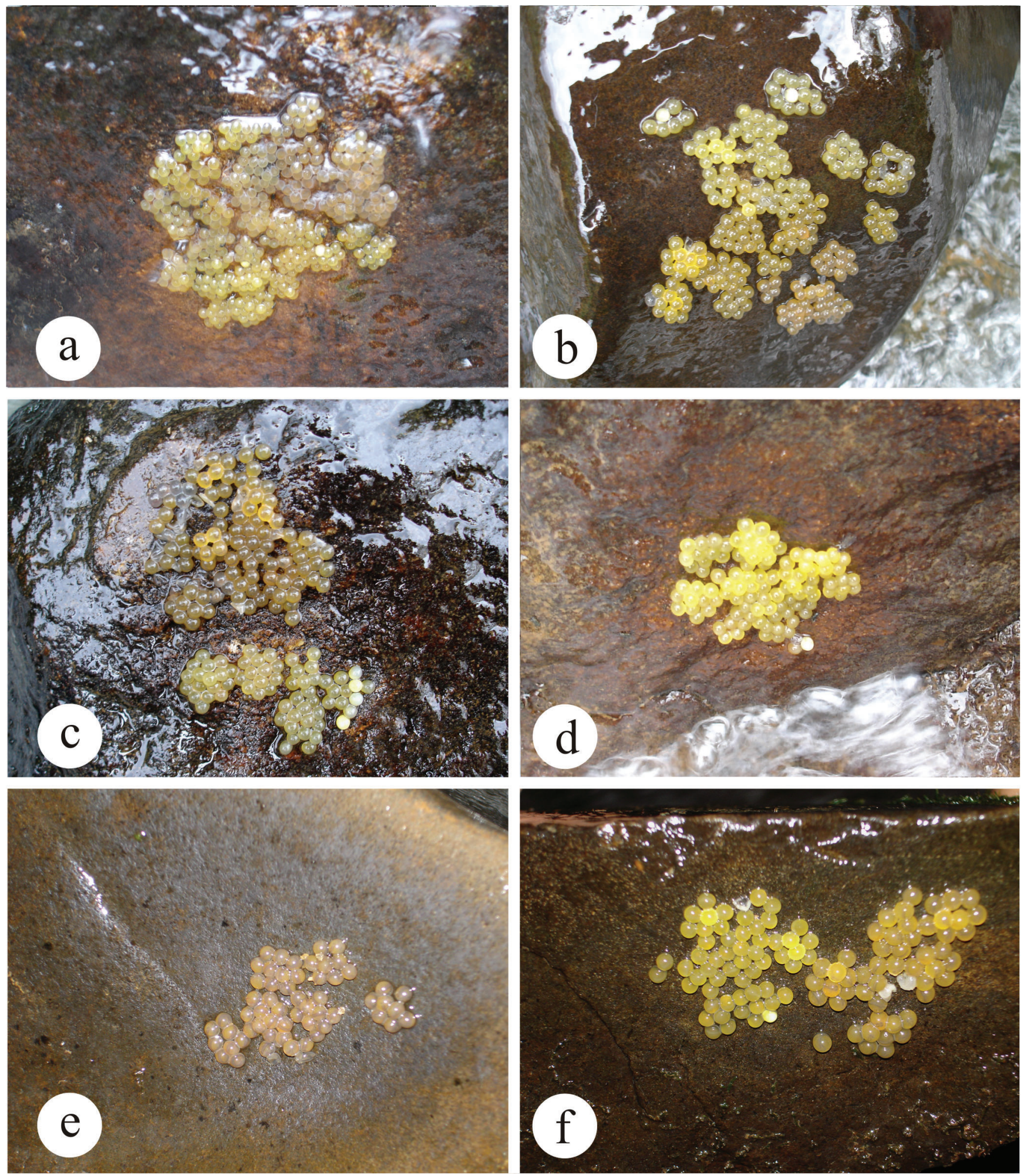

Figure 4. Spawns of Neoplecostomus microps found in the Macaé River at RM3: a - spawn I; b - spawn II; c-spawn III; d - spawn IV; e - spawn VII; f - spawn VIII. Yellow-gold eggs in early development and brown eggs in advanced stage of development. Mean size of eggs $=4.0 \mathrm{~mm}$

in a flash flood, risking the spawn of being crushed or predated if the stone is dislocated and the surface with the eggs is exposed. In addition, the position of the cavity in relation to the current may prevent sediments from accumulating on the eggs (Moodie \& Power 1982, Cruz \& Langeani 2000). Nests located in hydraulically protected areas can survive adverse conditions (i.e. flash floods) and assure the survival of the offspring (Constanz 1985).

Considering the larger size of males, low fecundity (Braga et al. 2008, Alves et al. unpublished), large eggs, and care in 
selecting the spawning site, probably the males of $N$. microps perform this function, as observed for most Loricariidae with this pattern of reproduction.

Sexual dimorphism has been detected in Neoplecostomus species where the males have developed odontodes and an extension in the head region (Zawadzki et al. 2008, Roxo et al. 2012, Andrade \& Langeani 2014). In N. microps, the sexual dimorphism observed in the genital area and in the pelvic fins had been poorly reported in literature. The distinctive papillae in male differ from the unique papilla in females, noted in immature specimens but most visible in adult. Other distinction between the sexes documented here is the epidermal projection on the pelvic-fin spine, present in males, even immature ones. Females did not express this modification in any life stage.

The identification of permanent external dimorphism is important for biological studies, because it eliminates the need for dissection to determine the sex of an individual. In the case of species such as $N$. microps, and of species that are targets of monitoring and conservation, population-monitoring protocols that allow determination of the sex ratio without killing individuals will be useful.

\section{Acknowledgments}

We thank all the members of the Laboratorio de Ecologia de Peixes (UFRJ) who helped us with the field and laboratory work, especially Victor Alves, Mayara A.L. Correia, Giuseppe C. Palermo, Gisela L.L. Cabral and Sérgio Teixeira. We are also grateful to the inhabitants of the Macaé River basin for their hospitality, especially to Sérgio Almeida, Geraldo Craik, Joceline Craik, Renaldo, Morais, Gracinha and Márcio Nascimento Silva. Thanks to Janet Read for revising the English version of the manuscript. The study was part of the project entitled "Estrutura da comunidade e estratégias reprodutivas e tróficas de peixes da bacia do rio Macaé, RJ" partially financed by $\mathrm{CNPq}$ and FAPERJ (respectively processes \#479257/2004-3 and E-26/ 171.672/2001). We also thank IBAMA for a collecting permit (Authorization 004/2004).

\section{References}

ALLAN, J.D. 1995. Stream Ecology: structure and function of running waters. London, Chapman \& Hall.

ANDRADE, B.N. \& LANGEANI, F. 2014. A new species of Neoplecostomus Eigenmann \& Eigenmann 1888 (Siluriformes, Loricariidae, Neoplecostominae) from the upper Rio Paraná basin. Neotrop. Ichthyol. 12: 675-681, http://dx.doi.org/10.1590/1982-022420130195

ARRATIA, G.A. 1983. Preferencias de habitat de peces Siluriformes de aguas continentales de Chile (Fam. Diplomystidae y Trichomycteridae). Stud. Neotrop. Fauna. E. 18: 217-237, doi: http://dx.doi.org/10.1080/ 01650528309360637

BALON, E.K. 1975. Reproductive guilds of fishes: a propoasal and definition. J. Fish. Res. Board. Can. 32: 821-864, http://dx.doi.org/ 10.1139/f75-110

BRAGA, F.M.S., GOMIERO, L.M. \& SOUZA, U.P. 2008. Aspectos da reprodução e alimentação de Neoplecostomus microps, (Loricariidae, Neoplecostominae) na microbacia do Ribeirão Grande, serra da Mantiqueira oriental (Estado de São Paulo). Acta Scient. Biol. Sci. 30: 455-463, http://dx.doi.org/10.4025/actascibiolsci.v30i4.301

BROOKS, S., TYLER, C.R. \& SUMPTER, J.P. 1997. Egg quality in fish: what makes a good egg? Rev. Fish. Biol. Fisher. 7: 387-416, http://dx.doi.org/10.1023/A:1018400130692
BROWN-PETERSON, N.J., WYANSKI, D.M., SABORIDO-REY, F., MACEWICZ, B.J. \& LOWERRE-BARBIERI, S.K. 2011. A standardized terminology for describing reproductive development in fishes. Mar. Coast. Fisheries 3: 52-70, http://dx.doi.org/10.1080/ 19425120.2011.555724

BROWN, S. \& ARMSTRONG, M.L. 1985. Propensity to drift downstream among various species of fishes. J. Fresh. Ecol. 3: 3-17, http:// dx.doi.org/10.1080/02705060.1985.9665087

BUCKUP, P.A. 2007. Família Loricariidae: Neoplecostominae. In Catálogo das espécies de peixes de água doce do Brasil (P.A. Buckup, N.A. Menezes \& M.S. Ghazzi, eds). Série Livros, 23. Rio de Janeiro, Museu Nacional. p. 82.

CONSTANZ, G.D. 1985. Allopternal care in the tessellanted darter, Etheostoma olmstedi (Pisces: Percidae). Environ. Biol. Fish. 14: 175-183, http://dx.doi.org/10.1007/BF00000824

CRUZ, A.L. \& LANGEANI, F. 2000. Comportamento reprodutivo do cascudo Liposarcus anisitsi (Eigenmann \& Kennedy, 1903) (Ostariophysi: Loricariidae: Hypostominae) em cativeiro. Comum. Mus. Cien. Tecnol. PUCRS. 13: 109-115.

EINUM, S. \& FLEMING, I.A. 2002. Does within-population variation in fish egg size reflect maternal influences on optimal values? Am. Nat. 160: 756-765, http://dx.doi.org/10.1086/343876

FERRARIS-JR, C.J. 2003. Subfamily Neoplecostominae. In Check List of the Freshwater Fishes of South and Central America (R.E. Reis, S.O. Kullander \& C.J. Ferraris-Jr., eds). Edipucrs, Porto Alegre, p. 319-320.

GARUTTI, V. \& FIGUEIREDO-GARUTTI, M.L. 2000. Migração lateral de Liposarcus anisitsi (Siluriformes, Loricariidae) no rio Preto, bacia do alto Paraná. Iheringia. 88: 25-31.

HORA, S.L. 1930. Ecology, bionomics and evolution of the torrential fauna, with special reference to the organs of attachment. Philos. T. R. Soc. Lon. B. 218: 171-282, http://dx.doi.org/10.1098/rstb.1930. 0005

KUNZ, Y.W. 2004. Developmental Biology of Teleost Fishes. Springer, Dordrecht, http://dx.doi.org/10.1007/978-1-4020-2997-4

LANGEANI, F. 1990. Revisão do gênero Neoplecostomus Eigenmann \& Eigenmann, 1888, com a descrição de quatro novas espécies do sudeste brasileiro (Ostariophysi, Siluriformes, Loricariidae). Comun. Mus. Cien. Tecnol. PUCRS. 3: 3-31.

MATTHEWS, W.J. 1998. Patterns in freshwater fish ecology. Chapman \& Hall, Massachusetts.

MENEZES, R.S. 1949. Incubação labial de ovos pelo macho de Loricaria typus Bleeker, da Lagoa do Peixe, Piauí, Brasil (Actinopterygii, Loricariidae, Loricariinae). R. bras. Biol. 9: 381-387.

M.M.A. - Ministério do Meio Ambiente. 2000. Avaliação e ações prioritárias para a conservação da biodiversidade da Mata Atlântica e Campos Sulinos. Ministério do Meio Ambiente, Brasília.

MOODIE, G.E.E. \& POWER, M. 1982. The reproductive biology of an armoured catfish, Loricaria uracantha, from Central America. Environ. Biol. Fish. 7: 143-148, http://dx.doi.org/10.1007/BF00 001784

NAKATANI, K., AGOSTINHO A.A., BAUMGARTNER, G., BIALETZKI, A., SANCHES, P.V., MAKRAKIS, M.C. \& PAVANELLI, C.S. 2001. Ovos e larvas de peixes de água doce: desenvolvimento e manual de identificação. EDUEM. Maringá.

NIKOLSKY, G.V. 1963. The ecology of fishes. Academic Press, London.

REIS, R.E., KULLANDER, S.O. \& FERRARIS-JR, C.J. 2003. Check list of the freshwater fishes of South and Central America. Edipucrs, Porto Alegre.

ROXO, F.F., OLIVEIRA, C. \& ZAWADZKI, C.H. 2012. Three new species of Neoplecostomus (Teleostei: Siluriformes, Loricariidae) from the upper Rio Paraná Basin of Southeastern Brazil. Zootaxa. 3233:1-21.

SABAJ, M.H., ARMBRUSTER, J.W. \& PAGE, L.M. 1999. Spawning in Ancistrus (Siluriformes: Loricariidae) with comments on the evolution of snout tentacles as a novel reproductive strategy: larval mimicry. Ichthyol. Explor. Fres. 10: 217-229. 
SCHMIDT, R.E. 2001. Loricaria cataphracta: parental care and description of early larvae. Ichthyol. Explor. Fres. 12: 235-240.

STURGES, H.A. 1926. The choice of a class interval. J. Am. Stat. Assoc. 21:65-66, http://dx.doi.org/10.1080/01621459.1926.10502161

TAYLOR, J.N. 1983. Field observation on the reproductive ecology of three species of armoured carfishes (Loricariidae: Loricariinae) in Paraguay. Copeia. 1983: 257-269, http://dx.doi.org/10.2307/ 1444726

VANNOTE, R.L., MINSHALL, G.W, CUMMINS, K.W., SEDELL, J.R. \& CUSHING, C.E. 1980. The river continuum concept.
Can. J. Fish. Aquat. Sci. 37: 130-137, http://dx.doi.org/10.1139/ f80-017

WEBB, P.W. 1989. Station-holding by three species of benthic fishes. J. Exp. Biol. 145: 303-320.

ZAR, J.H. 1996. Biostatistical analysis. Third edition. Prentice-Hall International Editions, New Jersey.

ZAWADZKI, C.H., PAVANELLI, C.S. \& LANGEANI, F. 2008. Neoplecostomus (Teleostei: Loricariidae) from the upper Rio Paraná basin, Brazil, with description of three new species. Zootaxa. 1757: $31-48$.

Received 8/06/2015

Revised 19/10/2015

Accepted 24/03/2016 